\title{
Tree seedling survival and growth in logged and undisturbed seasonal deciduous forest fragments in central Brazil
}

\author{
Ernestino de Souza Gomes Guarino • \\ Aldicir Osni Scariot
}

Received: 17 February 2011/Accepted: 19 April 2011/Published online: 27 August 2011

(C) The Japanese Forest Society and Springer 2011

\begin{abstract}
We evaluated the survival and growth of Amburana cearensis, Cedrela fissilis, and Sterculia striata seedlings in three seasonally tropical dry forest fragments that were subjected to different logging levels (intact, intermediately and heavily logged). In each fragment, we planted 40 seedlings of each species and monitored these over a period of 1 year. The highest seedling survival rate $(64 \%)$ occurred in the heavily logged fragment, which, however, also had the highest mortality risk for all species during the dry season. Only S. striata seedlings had different survival rates among the fragments. Height and diameter growth were higher at sites with higher canopy openness in the wet season. The survival and growth rates of seedlings planted in logged fragments indicate that this technique can be applied to restore and enrich logged forests of the Paranã River Basin.
\end{abstract}

Keywords Canopy openness · Drought - Logging · Paranã River Basin · Seedling establishment

\section{Introduction}

Located between the States of Goiás and Tocantins, the Paranã River Basin contains one of the main enclaves of deciduous forest of the Brazilian savannah biome (Scariot

E. de Souza Gomes Guarino $(\bowtie)$

Embrapa Acre, Rodovia BR-364, km 14,

PO Box 321, 69908-970 Rio Branco, Acre, Brazil

e-mail: esguarino@cpafac.embrapa.br

\section{A. O. Scariot}

Embrapa Genetic Resources and Biotechnology,

Parque Estação Biológica, Av. W5 Norte (final),

PO Box 02372, 70770-917 Brasília, Distrito Federal, Brazil and Sevilha 2005). Coexisting with distinct vegetation types (i.e., woodland savanna, riparian forests, and grasslands), the dry deciduous forests of the Paranã River Basin are known for their high number of valuable timber species, and because they are associated with nutrient-rich soils (Scariot and Sevilha 2005). The sum of these factors has resulted in intense human occupation in this region, usually based on selective use of wood and subsequent conversion of forest to pasture. Such land use has created a very fragmented landscape in which forest remnants with varying levels of exploitation exist in a matrix mainly composed of exotic pasture grasses (Scariot and Sevilha 2000, 2005).

Logging in the region is performed with little or no preexploratory planning (Instituto Brasileiro de Geografia e Estatística 1995), significantly altering the structure of the logged areas. According to Webb (1997), selective logging creates forest openings similar to natural treefall gaps. In seasonally tropical dry forests, the reduction of canopy cover may vary between $50 \%$ and $75 \%$ (Fredericksen and Mostacedo 2000; Vieira and Scariot 2008), causing severe and immediate environmental changes in the forest soil resulting from increases in the duration and intensity of solar radiation reaching the forest floor (Chazdon and Fetcher 1984).

The availability of sunlight caused by natural or anthropogenic gaps plays a key role in the initial development and survival of trees in tropical rain forests (Augspurger 1984; Bebber et al. 2002; Grogan et al. 2003). However, in seasonally tropical dry forests such as in the Paranã River Basin, soil moisture is the key factor in this process. In these forests, drought tolerance is essential for seed germination, survival, and growth of seedlings (Khurana and Singh 2001; Ceccon et al. 2006; Vieira and Scariot 2006). 
Seasonal forests go through long periods of drought, directly influencing phenological and ecophysiological processes (Borchert 1994). Temporal variations in soil moisture directly affect the survival and growth of seedlings, especially during the first year (Lieberman and $\mathrm{Li}$ 1992; Gerhardt 1996; Marod et al. 2002; McLaren and McDonald 2003). This period is considered the most sensitive in plant life cycles (Clark and Clark 1991; Osunkoya et al. 1992).

The decrease in canopy cover causes other biotic changes that may affect the regeneration of tree species. Newly germinated seedlings growing in treefall gaps are more likely to be attacked by herbivorous insects (Basset et al. 1998; Gerhardt 1998; Nichols et al. 1998; Jackson and Bach 1999) and mammals (Schupp 1988; Fredericksen and Fredericksen 2000; Ochoa 2000), increasing the herbivore pressure on seeds and seedlings in exploited areas (Howlett and Davidson 2003).

Regeneration of high-value timber species may be a limiting factor for sustainable management, and increasing the seedling densities of valuable species after logging is the first step towards sustainable forest management (Fredericksen and Mostacedo 2000). The aim of this study is to determine how establishment and initial development of seedlings are affected in fragments of a tropical dry forest under different levels of logging and disturbance.

\section{Materials and methods}

Study site

The study was conducted in three fragments of deciduous seasonal forest (Table 1), selected according to logging intensity (intact: Int, medium logged: ML, and heavily logged: HL). In general, logging activity in this region is illegal, and as a result, landowners avoid reporting detailed harvest information (Vieira and Scariot 2008); however, landowners of ML and HL fragments reported fires on their fragments after the harvest (Vieira 2002; Bueno 2003). All of the fragments are almost rectangular. The intact and heavily logged fragments are almost contiguous, separated only by a logging road, and are approximately $5 \mathrm{~km}$ from the intermediately logged fragment. During the long dry season, the planted pastures are dry, and all fragments are used as pasture for cattle, with approximately $0.5 \mathrm{cows} / \mathrm{ha}$ (Vieira and Scariot 2008).

All of the fragments studied are located in the Paranã River Basin (total area 59,403.00 $\mathrm{km}^{2}$ ). Seasonal forests are more frequently found in the Vão do Paranã geosystem, which presents low relief, with elevation between 400 and $600 \mathrm{~m}$ asl, with dark-red Podzol as the dominant soil (IBGE 1995). The climate is classified according to Köppen as Aw (dry winters), with mean annual temperature of $23.3^{\circ} \mathrm{C}$ and mean relative humidity of 67\% (IBGE 1995). From 1969 to 2002, the average rainfall in the Village of Estiva (approximately $20 \mathrm{~km}$ from the fragments) was $1,219 \mathrm{~mm}$ (Agência Nacional de Águas 2004). In 2003, the year in which this study was carried out, the rainfall was $1,023 \mathrm{~mm}$.

Species studied, seed collection, and seedling production

Amburana cearensis (Allemão) A.C. Sm. (Fabaceae), Cedrela fissilis Vell. (Meliaceae), and Sterculia striata A. St-Hil. \& Naudin (Malvaceae) reach the forest canopy. Sterculia striata was selected for having large seeds [fresh weight $=1.37 \mathrm{~g}$, seed size $($ width $/$ length $)=1.1 / 1.7 \mathrm{~cm}]$ and being dispersed by animals, an unusual pattern in this type of vegetation (Vieira and Scariot 2006, 2008). Amburana cearensis $(0.53 \mathrm{~g}, 1.1 / 1.6 \mathrm{~cm})$ and C. fissilis $(0.03 \mathrm{~g}, 0.5 / 1.0 \mathrm{~cm})$ were selected because they are classified as endangered, with high risk of future extinction (International union for conservation of nature 2010).

The seeds were collected at the study site between June and July 2002. To ensure genetic variability, seeds were
Table 1 Study site

characteristics

All fragments are almost rectangular

1 Vieira (2002)

${ }^{2}$ Bueno (2003)

${ }^{3}$ Scariot and Sevilha (2005)

\begin{tabular}{llll}
\hline & \multicolumn{2}{l}{ Study site } & \\
\cline { 2 - 4 } & Intact (Int) & Medium (ML) & Heavily (HL) \\
\hline Latitude & $13^{\circ} 39^{\prime} 24^{\prime \prime} \mathrm{S}$ & $13^{\circ} 36^{\prime} 29^{\prime \prime} \mathrm{S}$ & $13^{\circ} 39^{\prime} 35^{\prime \prime} \mathrm{S}$ \\
Longitude & $46^{\circ} 45^{\prime} 10^{\prime \prime} \mathrm{W}$ & $46^{\circ} 46^{\prime} 43^{\prime \prime} \mathrm{W}$ & $46^{\circ} 45^{\prime} 47^{\prime \prime} \mathrm{W}$ \\
Elevation (m) & 470 & 433 & 457 \\
Area (ha) & 212 & 163 & 115 \\
Logging year & & $1983-1996$ & 1997 \\
Density $\left(\mathrm{ind} \mathrm{ha}^{-1}\right)^{3}$ & - & 476 & 296 \\
Basal area $\left(\mathrm{m}^{2} \mathrm{ha}^{-1}\right)^{3}$ & 674 & 20.4 & 10.1 \\
Species richness $(S)^{3}$ & 24.5 & 39 & 33 \\
Shannon index $\left(H^{\prime}\right)^{3}$ & 48 & 2.92 & 2.62 \\
Equitability $(J)^{3}$ & 3.04 & 0.80 & 0.75 \\
\hline
\end{tabular}


collected from at least four individuals of each species and further mixed and processed in the Laboratory of Ecology and Conservation of Embrapa Genetic Resources and Biotechnology (Brasília/DF, Brazil), where the seedlings used in the experiments were produced. We planted the seeds in polyvinyl bags $14.5 \mathrm{~cm} \times 14.5 \mathrm{~cm}$ (diameter $\times$ height) filled with previously sterilized soil in early August 2002. Seedlings were maintained in a greenhouse with $70 \%$ shade until the first week of December 2002, when they were transported to the planting sites, where they were acclimated for 7 days under sunlight.

\section{Experimental design}

In the intact and intermediately logged fragments, a grid of 40 points was established along four parallel transects running perpendicular to the long axis of the fragments. On each line, 10 points were set at 40-m intervals. At each point, a seedling of each of the three species was planted, totaling 40 individuals of each species per fragment. Because of the shapes of the fragments, in the highly logged fragment the 40 points were arranged in a grid with eight parallel transects running perpendicular to the long axis of the fragment. Seedlings were distributed $0.5 \mathrm{~m}$ apart along a $1.0 \mathrm{~m}$ perpendicular to the main lines. Seedlings were always planted in the same order.

\section{Census and measurement of seedlings}

The seedlings were inspected monthly for 1 year, and any signs of predation, desiccation, trampling by cattle, or litterfall were recorded. The cause of death of each seedling was determined according to signs observed in the census of the previous month. When no sign was observed in the previous census, the cause of death was defined as indeterminate. The heights and diameters of the seedlings were measured immediately after planting and at 4 and 12 months.

To verify increases in height and diameter, the relative growth rate (RGR) was calculated by the following formula: $\mathrm{RGR}_{H}=\left(\ln H_{2}-\ln H_{1}\right) /\left(t_{2}-t_{1}\right)$, where $H_{2}$ and $H_{1}$ are the height (or diameter) at $t_{2}$ and $t_{1}$, respectively, and $t_{2}-t_{1}$ is the time elapsed between measurements, representing the growth in size per unit time (Hunt 1990).

\section{Environmental variables}

Canopy openness (\%), soil moisture, and leaf litter depth were estimated for each of the three fragments. Because of the great variance of these variables throughout the year, caused by the complete loss of tree leaves during the dry season, these variables were estimated twice: once in the middle of the wet season (January 2003) and once in the middle of the dry season (August 2003), except for leaf litter depth, which was estimated only during the dry season. In peaks of the wet season, there is no litter accumulation because of the rapid rate of decomposition at the beginning of this season (Martínez-Yrízar 1995). To avoid uncontrolled differences, all of the environmental variables were estimated on the same day.

The canopy openness within the forest was estimated using a spherical convex densiometer (Lemmon 1956). Measurements were taken at $0.5 \mathrm{~m}$ above the soil in the center of the planting row. At each point, four readings were made, toward each of the cardinal points, and the mean of the readings used.

Soil moisture in the fragments studied was estimated by the gravimetric method and represents the percentage of water in the soil's dry weight. We collected 15 soil samples in each fragment (at $0-10 \mathrm{~cm}$ depth) in each season (wet and dry), weighed each sample, then dried them at a temperature of $102^{\circ} \mathrm{C}\left( \pm 2^{\circ} \mathrm{C}\right)$ at 24 and $48 \mathrm{~h}$, and weighed them again.

The leaf litter thickness on the ground was estimated at 10 points per row by determining the number of leaves intercepted by the edge of a knife (Penã-Claros and de Boo 2002), considering the coverage of the litter in each planting row as the mean number of leaves intercepted at each point.

\section{Data analysis}

The canopy openness during wet and dry seasons and the leaf litter cover were analyzed using analysis of variance (ANOVA) and Tukey's honestly significant difference (HSD) test for multiple comparisons (Zar 1999). The $t$ test was used to verify differences between the canopy openness within the same fragment during wet and dry seasons. As the residuals were not normal (Shapiro-Wilk's test, $P>0.05)$ for performing statistical analyses, data were expressed as percentages and arcsine-transformed to perform statistical analyses (Zar 1999).

Seedling mortality was analyzed using survival rate analyses, as these represented the best option for analyzing survival data (Fox 1993). In survival analysis, the response variable is usually the time of an event of interest (Muenchow 1986; Colosimo 2001). In the present study, the response variable was the time elapsed from planting to the death of each seedling. A very important characteristic of the data used in this type of analysis is the existence of censored data, which are those occurring during partial response observation, i.e., the event does not occur before the end of the study period (Muenchow 1986; Fox 1993; Colosimo 2001). This type of censoring is the most common in ecological experiments (Pyke and Thompson 1986). 
In order to evaluate the function of survival, a KaplanMeier nonparametric estimator was used (Colosimo 2001). The log-rank test was used to compare the survival functions (Mantel-Haenszel test; Pyke and Thompson 1986). The hazard function was also calculated, which describes the probability of an event at time $t$ that had not occurred before (Pyke and Thompson 1986). A contingency table and chi-square test were used to verify whether there was a significant difference between the final survival rate of each species in different fragments (Zar 1999).

To test for differences among treatments in relative height and diameter growth rates for three time periods, ANOVA and Tukey's HSD test for multiple comparisons were used. The seedlings' increase in height and diameter during gaps in those periods were analyzed using the Mann-Whitney test. The growth of each species was also analyzed by multiple regression, using the canopy openness during wet and dry seasons and leaf litter cover as explanatory variables (Zar 1999).

All tests were performed with the program Statistica 5.5 (Statsoft Inc. 2000), except the chi-square test used to compare the final survival values, which was accomplished with the Bioestat 2.0 program (Ayres et al. 2000). Means are presented with standard deviations (mean \pm standard deviation). All statistical tests were performed with significance level $P<0.05$.

\section{Results}

Environmental variables

In the wet season, canopy openness was significantly different between the intact and logged fragments, although the intermediately and heavily logged fragments did not differ. However, in the dry season, canopy openness reflected logging intensity, with significant differences observed between all fragments $\left(F_{2,117}=\right.$ 40.11, $P \leq 0.0001$ ) (Table 2). A different pattern was described when the canopy openness in each fragment was compared between wet and dry seasons. In both periods, the intact fragment presented the least canopy openness, whereas in the dry period, the canopy openness was significantly greater in the heavily logged fragment (Table 2).

Soil moisture did not differ between the fragments in the wet season $\left(H_{2,45}=0.80, P=0.67\right)$ (Fig. 1); however, in the dry season, there was a significant difference between the fragments $\left(H_{2,45}=25.82, P \leq 0.0001\right)$ (Fig. 1). In this period, the soil moisture of the intermediately logged fragment $(9.12 \pm 1.57 \%)$ was almost twice that of the
Table 2 Study sites canopy openness (wet and dry seasons, mean $\pm \mathrm{SD}$ )

\begin{tabular}{lll}
\hline Study site & \multicolumn{2}{l}{ Canopy openness $(\%)$} \\
\cline { 2 - 3 } & Wet season & Dry season \\
\hline Intact & $9.76 \pm 3.33^{\text {a, A }}$ & $56.21 \pm 5.73^{\text {b, A }}$ \\
Medium & $16.83 \pm 9.65^{\text {a, B }}$ & $58.20 \pm 6.51^{\text {b, B }}$ \\
Heavily & $16.52 \pm 8.75^{\text {a, B }}$ & $68.13 \pm 6.67^{\text {b, C }}$ \\
\hline
\end{tabular}

Different lowercase letters indicate significant difference in canopy openness in the same fragment between periods $(P<0.05, t$ test $)$. Different uppercase letters indicate significant difference between the fragments in each period $(P<0.05$, analysis of variance and Tukey's honestly significant difference)

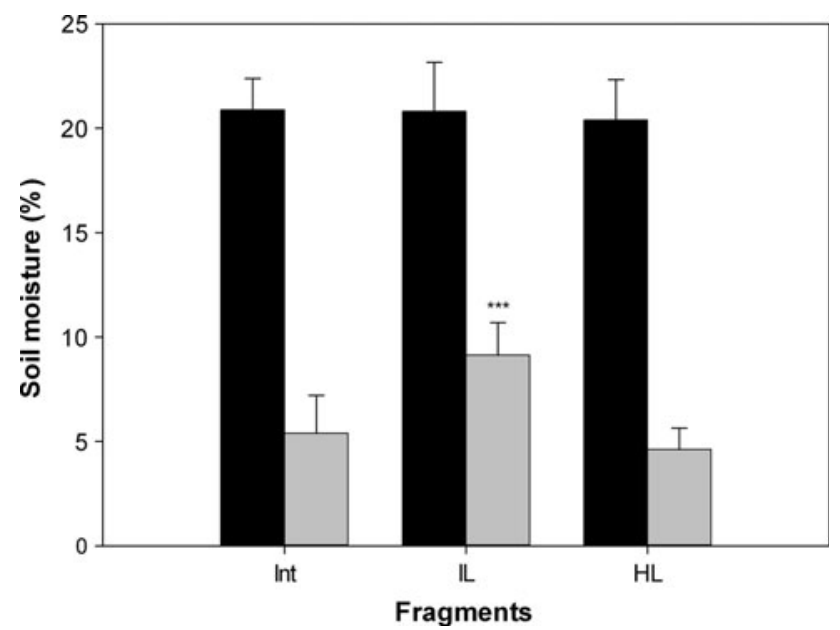

Fig. 1 Soil moisture (mean $\pm \mathrm{SD}$ ) in forest fragments. Int intact fragment, $I L$ intermediately logged fragment, $H L$ heavily logged fragment. Black bars wet season and gray bars dry season, $* * * P<0.05$

other fragments (intact $5.39 \pm 1.82 \%$, heavily logged $4.61 \pm 1.02 \%)$.

The leaf litter cover in the dry period did not differ between the intact $(1.47 \pm 0.45 \mathrm{~cm})$ and heavily logged $(1.26 \pm 0.04 \mathrm{~cm})$ fragments, although leaf litter cover in both fragments was significantly smaller than that of the intermediately logged fragment $\left(1.86 \pm 0.59 \mathrm{~cm} ; F_{2,117}=\right.$ 151.40, $P \leq 0.0001)$.

\section{Survival}

The survival curve for A. cearensis showed differences between the intermediately and heavily logged fragments (log-rank 2.44, $P \leq 0.01$ ), although no differences were observed between the intact and intermediately logged fragments (log-rank $-1.15, P=0.248$ ) or the intact and heavily logged fragments (log-rank 1.80, $P=0.071$ ). Survival curves did not differ in any fragment for 
C. fissilis [log-rank (intact vs. intermediately logged) 0.48 , $P=0.63$; (intact vs. heavily logged) $1.61, P=0.11$; (intermediately vs. heavily logged) $0.89, P=0.37$ ]. Sterculia striata survival curves showed differences between the intact and intermediately logged fragments (log-rank $3.25, P \leq 0.01)$ and the intermediately and heavily logged fragments (log-rank 4.54, $P \leq 0.001$ ). No difference was observed between the intact and heavily logged fragments (log-rank 1.71, $P=0.08)$.

The overall seedling survival after 12 months of planting differed between fragments $(11.86$, g.l. $=2$, $P \leq 0.01$ ), with the highest survival rate in the heavily logged fragment, at $64 \%(n=77)$, followed by the intact $(50 \%, n=60)$ and intermediately logged fragments $(41 \%$, $n=49$ ). Only $S$. striata presented different survival rates between fragments $\left(\chi^{2}=17.42\right.$, g.l. $\left.=2, P \leq 0.001\right)$, with the highest survival rate in the heavily logged fragment $(80 \%, n=32)$, followed by the intact $(65 \%, n=26)$ and intermediately logged fragments $(35 \%, n=14)$. The same pattern was observed for Amburana cearensis, although its survival rates did not differ between fragments $\left(\chi^{2}=3.27\right.$, g.l. $=2, P=0.195$; heavily: $60 \%, \mathrm{n}=24$; intact: $42.5 \%$, $n=17$; intermediately: $40 \%, n=16$ ). The highest survival rate for Cedrela fissilis was observed, again, in the heavily logged fragment $(52.5 \%, n=21)$; however, the intermediately logged fragment survival rate was greater than that of the intact forest fragment (intermediately: $47.5 \%, n=19$; intact: $42.5 \%, n=17$ ), and like A. cearensis its survival rates did not differ between fragments $\left(\chi^{2}=0.868\right.$, g.l. $\left.=2, P=0.648\right)$.

During rainfall events, seedlings in the heavily logged fragment had the lowest probability of death $(P \leq 0.05)$ (Fig. 2). With the beginning of dry season, this probability reached maximum values of 0.15 for $C$. fissilis, 0.13 for A. cearensis, and 0.03 for S. striata. In the intact fragment, the hazards function did not present a clear pattern, with changing peaks of higher probability of death at the beginning and at the end of drought (Fig. 2), unlike the other fragments, for which the highest probability of death occurred during the wet season. The probability of death of seedlings in the intermediately logged fragment was concentrated in the first 4 months (Fig. 2), whereas in the heavily logged fragment it was concentrated in the last 3 months (Fig. 2).

Because of the elapsed time between censuses-30 days on average-it was only possible to precisely identify the cause of death of half of the seedlings. Thus, the most common causes of mortality were desiccation (20\%, $n=35)$, herbivory $(19.5 \%, n=34)$, physical damage caused by falling branches $(7 \%, n=12)$, and trampling by cattle $(3.5 \%, n=6)$. Attack by herbivores was greatest in the intermediately logged fragment, causing the death of $28 \%$ of the seedlings $(n=19)$.
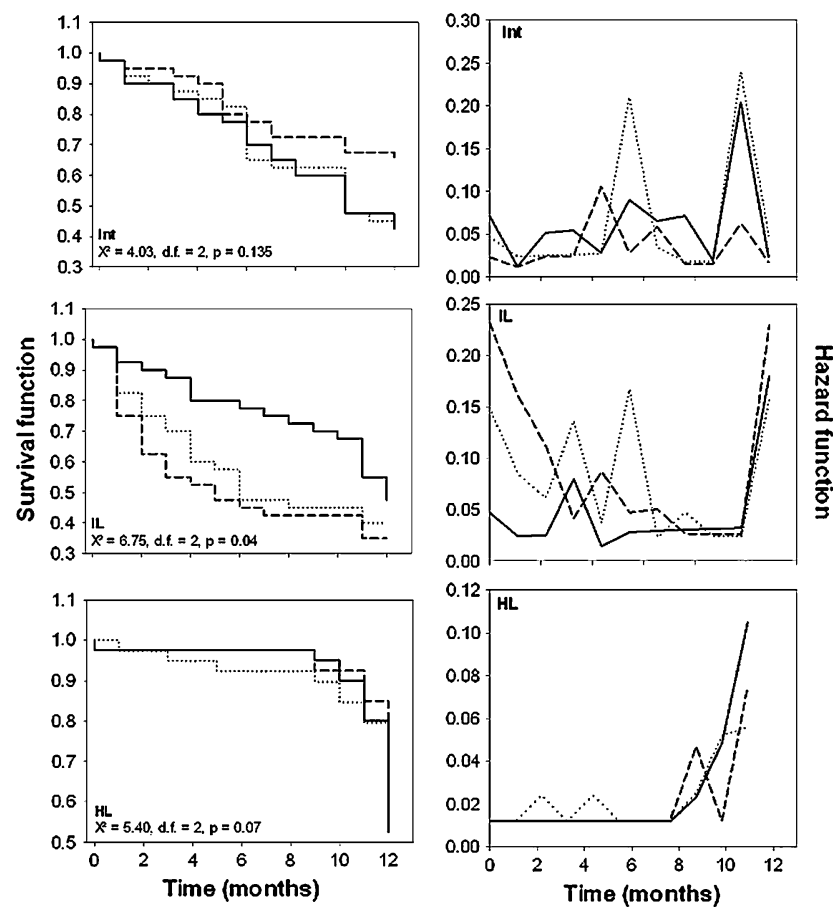

Fig. 2 Survival and hazard functions for Amburana cearensis (dashed dot line), Cedrela fissilis (entire line), and Sterculia striata (dashed line) in studied fragments. The period of drought is concentrated between the months of April (month 4) and October (month 10)

\section{Growth}

In all species and fragments studied, growth was limited to the wet season. The ANOVA of the increments in height and diameter (RGR) indicated that, 12 months after planting, only $C$. fissilis grew differently in different fragments (Table 3). The greatest increase in height and diameter for $C$. fissilis occurred in the intermediately logged fragment (height $=18.73 \pm 9.71 \mathrm{~cm}$, diameter $=4.06 \pm 2.30$ ) (Fig. 3), with no significant difference in increases between the heavily logged and intact fragments (heavily logged: height $=10.48 \pm 9.31 \mathrm{~cm}$, diameter $=1.25 \pm 2.98 ; \quad$ intact: height $=7.18 \pm 5.94 \mathrm{~cm}$, diameter $=1.26 \pm 2.44$ ). For S. striata, the increase in height was lowest in the intermediately logged fragment from zero to 4 months and from 4 to 12 months, but this difference was still present after 12 months. The increase in diameter for this species at the end of the study in the intermediately logged fragment was negative (Fig. 3; Table 3).

The multiple regression with the increments in height, diameter, and canopy openness during wet and dry seasons and leaf litter cover showed positive relationships for all species; however, no meaningful case (Table 4) was found to indicate that the model used was inadequate to explain the increases. 
Table 3 ANOVA summary for the increase in height $(\mathrm{cm})$ and diameter $(\mathrm{cm})$ after 4 months of planting (Dec 2002-Apr 2003), between 4 and 12 months (Apr 2003-Dec 2003), and the end of the study (after 12 months, Dec 2002-Dec 2003)

\begin{tabular}{|c|c|c|c|c|c|c|c|c|c|c|}
\hline \multirow[t]{2}{*}{ Species } & \multirow{2}{*}{$\begin{array}{l}\text { Source of } \\
\text { variation }\end{array}$} & \multicolumn{3}{|c|}{ Dec 2002-Apr 2003} & \multicolumn{3}{|c|}{ Apr 2003-Dec 2003} & \multicolumn{3}{|c|}{ Dec 2002-Dec 2003} \\
\hline & & $d f$ & $F$ & $P$ & $d f$ & $F$ & $P$ & $d f$ & $F$ & $P$ \\
\hline \multirow[t]{2}{*}{ A. cearensis (height) } & Study site & 2 & 1.05 & 0.353 & 2 & 1.24 & 0.297 & 2 & 0.36 & 0.696 \\
\hline & Error & 91 & & & 54 & & & 54 & & \\
\hline \multirow[t]{2}{*}{ A. cearensis (diameter) } & Study site & 2 & 1.03 & 0.362 & 2 & 2.50 & 0.091 & 2 & 2.87 & 0.06 \\
\hline & Error & 91 & & & 54 & & & 54 & & \\
\hline \multirow[t]{2}{*}{ C. fissilis (height) } & Study site & 2 & 1.01 & 0.367 & 2 & 17.08 & $\leq 0.001 *$ & 2 & 5.15 & $0.008^{*}$ \\
\hline & Error & 101 & & & 54 & & & 54 & & \\
\hline \multirow[t]{2}{*}{ C. fissilis (diameter) } & Study site & 2 & 0.31 & 0.735 & 2 & 6.03 & $0.004 *$ & 2 & 5.99 & $0.004 *$ \\
\hline & Error & 101 & & & 54 & & & 54 & & \\
\hline \multirow[t]{2}{*}{ S. striata (height) } & Study site & 2 & 8.74 & $\leq 0.001 *$ & 2 & 3.26 & $0.044 *$ & 2 & 2.45 & 0.094 \\
\hline & Error & 92 & & & 69 & & & 69 & & \\
\hline \multirow[t]{2}{*}{ S. striata (diameter) } & Study site & 2 & 1.03 & 0.362 & 2 & 2.17 & 0.122 & 2 & 0.30 & 0.738 \\
\hline & Error & 92 & & & 69 & & & 69 & & \\
\hline
\end{tabular}

$* P<0.05$

\section{Discussion}

An increase in canopy openness, a direct result of selective logging, results in biophysical changes in the forest soil, mainly decreasing soil moisture (Bawa and Seidler 1998). In seasonally tropical dry forests, in which soil moisture is the key factor in the initial process of recruiting seeds (Khurana and Singh 2001), logging apparently increases the negative effect of low soil moisture. The increased exposure of soil to solar radiation due to reduced coverage of the canopy and decreased rainfall between May and October, when average rainfall is only $48 \mathrm{~mm}$, reduced soil moisture from an average of $20 \%$ in all of the fragments to less than $5 \%$ in the heavily logged fragment. Therefore, the seedlings in this fragment were the most affected by these changes. Even with the highest seedling survival rates at the end of 1 year (Amburana cearensis: 60\%, Cedrela fissilis: 52.5\%, and Sterculia striata: $80 \%$ ), most deaths in this fragment were concentrated during the dry period.

The demand for shade in the initial period of a species' life can be understood as an ecological property incorporating tolerance to drought and availability of light (Ray and Brown 1995). In seasonally tropical dry forests, demand for shade, rather than tolerance of shade, is a more adequate model for predicting survival of seedlings (Ceccon et al. 2003, 2004). Gerhardt (1996) found higher survival rates of Cedrela odorata seedlings in a secondary seasonal forest in Costa Rica in shaded areas, as opposed to the findings of Ricker et al. (2000) for the same species in a tropical rain forest in Mexico with shadier conditions than those of seasonal forests. According to these authors, an ideal canopy gap for C. odorata is between $78 \%$ and $100 \%$. Cedrela fissilis is less umbropilous in the early period, with a photosynthetic compensation point close to that of a heliophilous species (Inoue 1980). This may explain the pattern found for survival of this species.

Unlike with survival, the growth of this species is affected by different levels of canopy openness, increasing in sites with more sunlight availability (Santos et al. 2006). Comparatively, $C$. fissilis presented the greatest increase in height and diameter at the end of the study, mainly in the intermediately logged forest fragment. During rainfall events, this fragment has a canopy openness equal to the most exploited fragment. Like C. fissilis, S. striata is a heliophilous (Lorenzi 1992) and partial-shade tolerant plant (Mostacedo and Fredericksen 2000). The high survival rate of this species in the most heavily logged fragment can be explained by the stage of ecological succession of each species. Although $C$. fissilis is described as a late successional or even climax species (Barbosa 2000; Moreira and Silva 2004), S. striata is described as an early secondary species (Moreira and Silva 2004), presenting a survival rate of more than $96 \%$ in some cases (Parron et al. 2000). Unlike the intact and heavily logged fragments, the intermediately logged fragment presented a low mortality rate of seedlings by desiccation. In the drought season, this fragment has the highest moisture and leaf litter cover. Leaf litter cover can reduce the temperature and water loss by evaporation (Facelli 1994; Gerhardt 1996), positively affecting the survival of seedlings (Molofsky and Augspurger 1992; Cintra 1997).

The low availability of water in the soil, in addition to increasing the mortality of seedlings during drought, also limits their growth during periods of rainfall (Gerhardt 1996). In the first 4 months after planting (January to April), there was a positive growth in diameter in all 

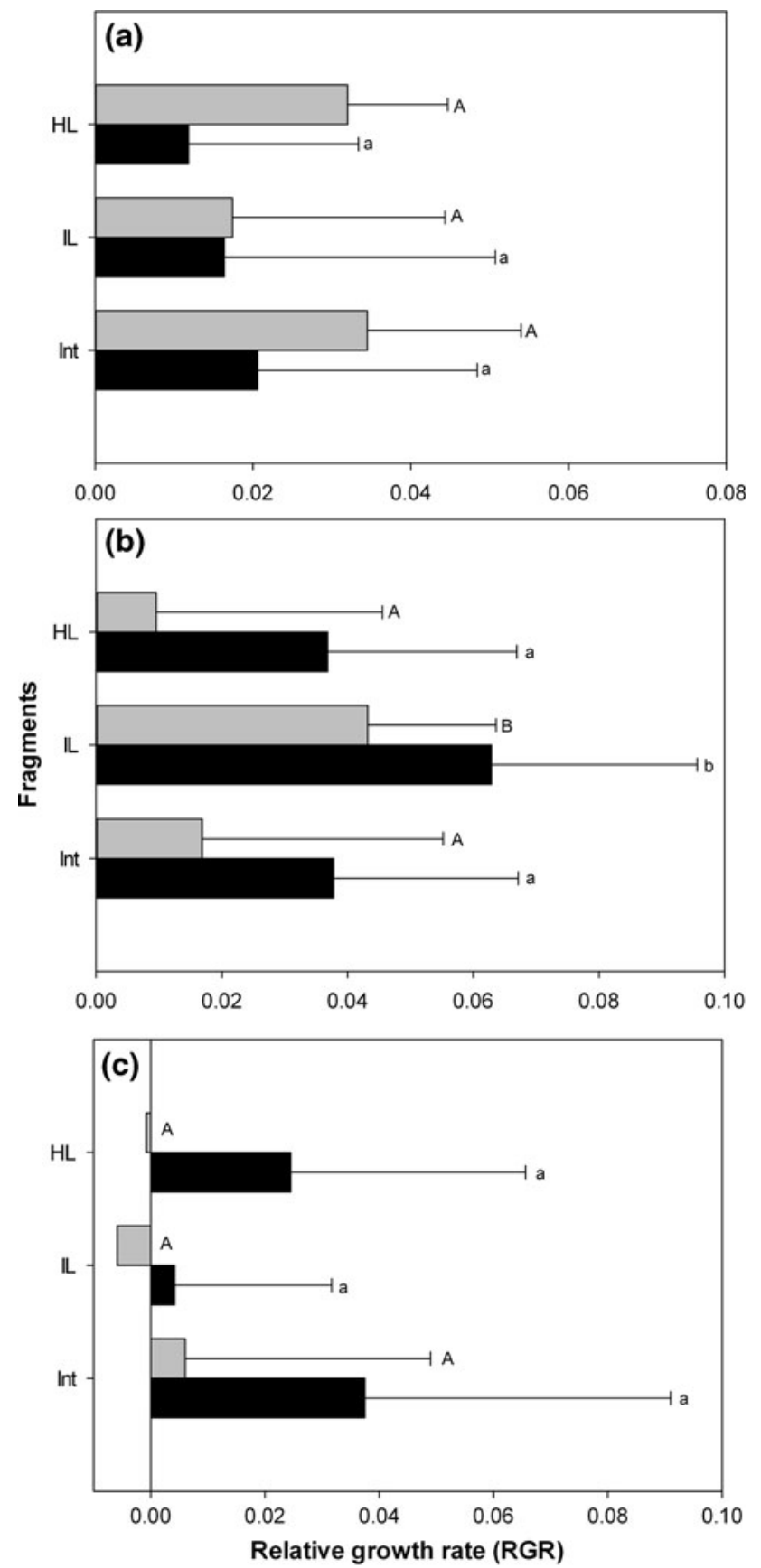

Fig. 3 Relative growth rate (RGR) after 12 months for the species studied (mean $\pm \mathrm{SD}$ ). Gray bars diameter RGR, black bars height RGR. a Amburana cearensis, b Cedrela fissilis, and c Sterculia striata. Different letters indicate significant difference, $P<0.05$ by analysis of variance and Tukey's honestly significant difference

species in two of the three fragments studied; however, between March and December, the increments were close to zero or even negative. The reduction in diameter during drought has also been reported for large deciduous trees in seasonal forests (Reich and Borchert 1982) and in seedlings in semideciduous and deciduous forests in Costa Rica
Table 4 Summary of multiple regression for the increments in height and diameter in the fragments studied after 12 months

\begin{tabular}{lcc}
\hline Species & RGR (high) & RGR (diameter) \\
\hline A. cearensis & $r^{2}=0.04, F=0.68$, & $r^{2}=0.13, F=2.62$, \\
$(n=57)$ & $P=0.57$ & $P=0.06$ \\
C. fissilis & $r^{2}=0.05, F=1.00$, & $r^{2}=0.12, F=2.48$, \\
$(n=57)$ & $P=0.40$ & $P=0.07$ \\
S. striata & $r^{2}=0.04, F=0.94$, & $r^{2}=0.04, F=1.58$, \\
$(n=72)$ & $P=0.43$ & $P=0.20$ \\
\hline
\end{tabular}

(Gerhardt 1996). According to Rincón and Huante (1993), apart from the successional classification of each species (pioneer, secondary or climax), seedlings of tree species in seasonal forests grow better in environments with greater availability of sunlight, similar to what has been described for seedlings in gaps in tropical rain forests (Augspurger 1984; Howe 1990; Poorter and Hayashida-Oliver 2000).

As previously discussed, most of the mortality was caused by desiccation. However, the low mortality of seedlings by physical damage caused by litterfall must be emphasized. Among the seedlings whose cause of death was identified, only $7 \%$ were attributed to this cause. Physical damage assessments by artificial models of seedlings suggest that, in tropical forests, litterfall is the most common cause of mortality (Clark and Clark 1989; Mack 1998; Scariot 2000). This cause may vary depending on the forest and the species studied, and any generalization on this issue should be made very carefully. The large amount of falling leaves and branches during drought in this forest type was expected to result in a greater proportion of seedling death in this study, particularly in the most heavily exploited fragments.

Ray and Brown (1995) suggest planting of seedlings as the best method for starting the recovery of tropical dry forests in the Caribbean. The high survival rates of all species studied, mainly in the heavily logged forest fragment, opens up the possibility of using this technique for the species studied in the recovery of forests that have been heavily exploited in the Paranã River Basin. Seedling planting for enriching/improving gaps and forests with lower levels of exploitation is also recommended, especially for A. cearensis, an endangered species with low natural occurrence in the fragments studied (Bueno 2003). All results should be cautiously reviewed, however, because in addition to the relatively short period of study, with only 1 year of follow-up, each level of exploitation was represented by only one fragment.

Acknowledgments This research was funded by Embrapa Recursos Genéticos e Biotecnologia and Fundo Nacional de Meio Ambiente (FNMA). The first author received a fellowship from the Conselho Nacional de Desenvolvimento Científico e Tecnológico (CNPq) and Coordenação de Aperfeiçoamento de Pessoal de Nível Superior 
(CAPES). We are indebted to Daniel Vieira, Alexandre Bonesso, Anderson Sevilha, and Mauricio Bonesso for productive discussions and for help in analyzing and interpreting the results.

\section{References}

Agência Nacional de Águas (2004) Sistema de informações hidrológicas (Hidroweb). http://www.ana.gov.br. Accessed 26 Mar 2010

Augspurger CK (1984) Light requirements of neotropical tree seedlings: a comparative study of growth and survival. J Ecol 72:777-795

Ayres M, Ayres JR, M, Ayres DL, Santos, AAS (2000) Bioestat 2.0: aplicações estatísticas nas áreas de ciências biológicas e médicas. Sociedade Civil Mamirauá/MCT—CNPq, Belém

Barbosa LM (2000) Considerações gerais e modelos de recuperação de formações florestais. In: Rodrigues RR, Leitão Filho HF (eds) Matas ciliares: conservação e recuperação. Editora da Universidade de São Paulo, São Paulo

Basset Y, Novotny V, Miller SE, Springate ND (1998) Assessing the impact of forest disturbance on tropical invertebrates: some comments. J Appl Ecol 35:461-466

Bawa KS, Seidler R (1998) Natural forest management and conservation of biodiversity in tropical forests. Conserv Biol 12:46-55

Bebber D, Brown N, Speight M, Moura-Costa P, Wai Y (2002) Spatial structure of light and dipterocarp seedling growth in a tropical secondary forest. Forest Ecol Manag 157:65-75

Borchert R (1994) Soil and stem water storage determine phenology and distribution of tropical dry forest trees. Ecology 75:1437-1449

Bueno PC (2003) Estrutura de populações, germinação e longevidade de sementes de árvores de Floresta Estacional Decidual. Dissertation (Master in Ecology), Universidade de Brasília

Ceccon E, Huante P, Campo J (2003) Effects of nitrogen and phosphorus fertilization on the survival and recruitment of seedlings of dominant tree species in two abandoned tropical dry forests in Yucata'n, Mexico. For Ecol Manag 182:387-402

Ceccon E, Sánchez S, Campo J (2004) Tree seedling dynamics in two abandoned tropical dry forests of differing successional status in Yucatán, Mexico: a field experiment with $\mathrm{N}$ and $\mathrm{P}$ fertilization. Plant Ecol 170:277-285

Ceccon E, Huante P, Rincón E (2006) Abiotic factors influencing tropical dry forests regeneration. Braz Arch Biol Technol 49:305-312

Chazdon RL, Fetcher N (1984) Photosynthetic light environments in a lowland tropical rain forest in Costa Rica. J Ecol 72:553-564

Cintra R (1997) Leaf litter effects on seed and seedling predation of the palm Astrocaryum murumuru and the legume tree Dipteryx micrantha in Amazonian Forest. J Trop Ecol 13:709-725

Clark DB, Clark DA (1989) The role of physical damage in the seedling mortality regime of a neotropical rain forest. Oikos $55: 225-230$

Clark DB, Clark DA (1991) The impact of physical damage on canopy tree regeneration in tropical rain-forest. $\mathrm{J}$ Ecol 79:447-457

Colosimo E (2001) Análise de sobrevivência aplicada. In: $46^{\circ}$ Reunião anual da região brasileira da sociedade Internacional de biometria. RBRAS, Piracicaba

Facelli JM (1994) Multiple indirect effects of plant litter affect the establishment of woody seedlings in old fields. Ecology 75:1727-1735

Fox GA (1993) Failure-time analysis: emergence, flowering, survivorship, and other waiting times. In: Scheiner SM, Gurevitch J (eds) Design and analysis of ecological experiments. Chapman and Hall, New York
Fredericksen NJ, Fredericksen TS (2000) Respuesta de la fauna terrestre al aprovechamiento forestal y los incendios en un bosque humedo tropical en Bolivia. Documento técnico 89/2000, Proyeto BOLFOR, Santa Cruz

Fredericksen TS, Mostacedo B (2000) Regeneration of timber species following selection logging in a Bolivian tropical dry forest. Forest Ecol Manag 131:47-55

Gerhardt K (1996) Effects of root competition and canopy openness on survival and growth of tree seedlings in a tropical seasonal dry forest. Forest Ecol Manag 82:33-48

Gerhardt K (1998) Leaf defoliation of tropical dry forest tree seedlings-implications for survival and growth. Trees-Struct Funct 13:88-95

Grogan J, Ashton MS, Galvão J (2003) Big-leaf mahogany (Swietenia macrophylla) seedling survival and growth across a topographic gradient in southeast Pará, Brazil. Forest Ecol Manag 186:311-326

Howe HF (1990) Survival and growth of juvenile Virola surinamensis in Panama: effects of herbivory and canopy closure. J Trop Ecol 6:259-280

Howlett BE, Davidson DW (2003) Effects of seed availability, site conditions, and herbivory on pioneer recruitment after logging in Sabah, Malaysia. Forest Ecol Manag 184:369-383

Hunt R (1990) Basic growth analysis. Unwin Hyman, London

Inoue MT (1980) Photosynthesis and transpiration in Cedrela fissilis Vell. seedlings in relation to light intensity and temperature. Turrialba 30:280-283

Instituto Brasileiro de Geografia e Estatística (IBGE) (1995) Zoneamento geoambiental e agroecológico do estado de Goiás: região nordeste. IBGE/Divisão de Geociências do Centro-Oeste, Rio de Janeiro

International union for conservation of nature (2010) IUCN Red list of threatened species. http://www.iucnredlist.org. Accessed 27 Mar 2010

Jackson RV, Bach CE (1999) Effects of herbivory on growth and survival of seedlings of a rainforest tree, Alphitonia whitei (Rhamnaceae). Aust J Ecol 24:278-286

Khurana E, Singh JS (2001) Ecology of seed and seedling growth for conservation and restoration of tropical dry forest: a review. Environ Conserv 28:39-52

Lemmon PE (1956) A spherical densiometer for estimating forest overstory density. Forest Sci 2:314-320

Lieberman D, Li MG (1992) Seedling recruitment patterns in a tropical dry forest in Ghana. J Veg Sci 3:375-382

Lorenzi H (1992) Árvores brasileiras: manual de identificação e cultivo de plantas arbóreas nativas do Brasil. Instituto Plantarum, Nova Odessa

Mack AL (1998) The potential impact of small-scale physical disturbance on seedlings in a papuan rainforest. Biotropica 30:547-552

Marod D, Kutintara U, Tanaka H, Nakashizuka T (2002) The effects of drought and fire on seed and seedling dynamics in a tropical seasonal forest in Thailand. Plant Ecol 161:41-57

Martínez-Yrízar A (1995) Biomass distribution and primary productivity of tropical dry forests. In: Bullock SH, Mooney HA, Medina E (eds) Seasonally dry tropical forests. Cambridge University Press, Cambridge

McLaren KP, McDonald MA (2003) The effects of soil moisture and shade on seed germination and seedling survival in a tropical dry forest in Jamaica. Forest Ecol Manag 183:61-75

Molofsky J, Augspurger CK (1992) The effect of leaf litter on early seedling establishment in a tropical forest. Ecology 73:68-77

Moreira PR, Silva OA (2004) Produção de serapilheira em área reflorestada. Rev Árvore 28:49-59

Mostacedo JB, Fredericksen TS (2000) Estado de regeneración de especies florestales importantes en Bolivia: evaluación y 
recomendaciones. Documento técnico 88/2000, Proyeto BOLFOR, Santa Cruz

Muenchow G (1986) Ecological use of failure time analysis. Ecology 67:246-250

Nichols JD, Wagner MR, Agyeman VK, Bosu P, Cobbinah JR (1998) Influence of artificial gaps in tropical forest on survival, growth, and Phytolyma lata attack on Milicia excelsa. Forest Ecol Manag 110:353-362

Ochoa GJ (2000) Efectos de la extracción de madera sobre la diversidad de mamíferos pequeños en bosque de tierras bajas de la Guayana Venezolana. Biotropica 32:146-164

Osunkoya OO, Ash JE, Hopkins MS, Graham AW (1992) Factors affecting survival of tree seedlings in North Queensland rainforests. Oecologia 91:569-578

Parron LM, Ribeiro JF, Martínez-Ramos LL (2000) Revegetação de uma área degradada no Córrego Sarandi, Planaltina, DF. Boletim do Herbário Ezechias de Paulo Heringer 5:88-102

Penã-Claros M, de Boo H (2002) The effect of forest successional stage on seed removal of tropical rain forest tree species. J Trop Ecol 18:261-274

Poorter L, Hayashida-Oliver Y (2000) Effects of seasonal drought on gap and understorey seedlings in a Bolivian moist forest. J Trop Ecol 16:481-498

Pyke DA, Thompson JN (1986) Statistical analysis of survival and removal rate experiments. Ecology 67:240-245

Ray GJ, Brown BJ (1995) Restoring Caribbean dry forests: evaluation of tree propagation techniques. Restor Ecol 3:86-94

Reich PB, Borchert R (1982) Phenology and ecophysiology of the tropical tree, Tabebuia neochrysantha (Bignoniaceae). Ecology 63:294-299

Ricker M, Siebe C, Sánchez S, Shimada K, Larson BC, MartinezRamos M, Montagnini F (2000) Optimising seedling management: Pouteria sapota, Diospyros digyna, and Cedrela odorata in a Mexican rainforest. Forest Ecol Manag 139:63-77

Rincón E, Huante P (1993) Growth responses of tropical deciduous tree seedlings to contrasting light conditions. Trees-Struct Funct $7: 202-207$
Santos DL, Rakocevic M, Takaki M, Ribaski J (2006) Morphological and physiological responses of Cedrela fissilis Vellozo (Meliaceae) seedlings to light. Braz Arch Biol Technol 49:171-182

Scariot A (2000) Seedling mortality by litterfall in Amazonian forest fragments. Biotropica 32:662-669

Scariot A, Sevilha AC (2000) Diversidade, Estrutura e manejo de florestas deciduais e as estratégias para a conservação. In: Cavalcanti TB, Walter BMT (eds.) Tópicos atuais em botânica: palestras convidadas do $51^{\circ}$ Congresso Nacional de Botânica. Embrapa Recursos Genéticos e Biotecnologia, Brasília

Scariot A, Sevilha AC (2005) Biodiversidade, estrutura e conservação de Florestas Estacionais Deciduais no Cerrado. In: Scariot A, Sousa-Silva JC, Felfili JM (eds.) Cerrado: ecologia, biodiversidade e conservação. Ministério do Meio Ambiente, Brasília

Schupp EW (1988) Seed and early seedling predation in the forest understory and in treefall gaps. Oikos 51:71-78

Statsoft Inc. (2000) Statistica for Windows: computer program manual. Statsoft Inc., Tulsa

Vieira DLM (2002) Efeitos da exploração madeireira na estrutura populacional e regeneração de árvores de floresta estacional decidual. Dissertation (Master in Ecology), Universidade de Brasília

Vieira DLM, Scariot A (2006) Effects of logging, liana tangles and pasture on seed fate of dry forest tree species in Central Brazil. Forest Ecol Manag 230:197-205

Vieira DLM, Scariot A (2008) Environmental variables and tree population structures in deciduous forests of Central Brazil with different levels of logging. Braz Arch Biol Technol 51:419-431

Webb EL (1997) Canopy removal and residual stand damage during controlled selective logging in lowland swamp forest of northeast Costa Rica. Forest Ecol Manag 95:117-129

Zar JH (1999) Biostatistical analysis. Prentice Hall, New Jersey 